\title{
THE COHESIVENESS OF MUSLIM PANGESTU MEMBERS IN SALATIGA, CENTRAL JAVA
}

\section{S. Suciati}

Muhammadiyah University of Yogyakarta, Indonesia

email:suciatiumy@yahoo.co.id

\section{ABSTRACT}

The drying of spirituality and weakening of cohesiveness in the midst of materialistic hedonistic modern world become major challenge for the adherents of official religions in Indonesia. The practice of religions is considered too much focusing on ritual aspects. Therefore, those teachings cannot give the real meaningfulness of religious life. Consequently, some adherents of official religions begin to see other spiritual/mysticism sects. This study describes the social cohesiveness among muslims who become members of Pangestu, a spiritual-mysticism sect widely spreading among Javanese society in Indonesia. This research shows that the Pangestu in Salatiga, Central Java, can fulfill social, economic, and spiritual needs of its members. Among the underlying factors that make Pangestu succeed to meet its members' needs and expectations are the capability of the members to intensely communicate with each other through meetings and bawaraos (Jv, informal gathering), the great concern between members, good-example of leadership, the defense of Pangestu's good name, and the satisfaction in experiencing meaningfulness of religious practices.

Kekeringan spiritual dan lemahnya kebersamaan di tengah dunia modern yang serba hedonistik menjadi tantangan utama bagi para pemeluk agama di Indonesia. Praktik-praktik keagamaan terlalu banyak terfokus pada aspek ritual, sehingga ajaran agama tidak. mampu menghadirkan praktekpraktek keagamaan yang benar-benar bermakna. Hal ini mendorong sebagian pemeluk agama untuk melirik aliran kepercayaan dan kebatinan. Artikel ini mendeskripsikan keguyuban sosial di antara orang-orang Islam yang menjadi anggota Pangestu, sebuah aliran kepercayaan di Indonesia yang 
banyak menyebar terutama di kalangan masyarakat Jawa. Penelitian ini menunjukkan bahwa Pangestu di Salatiga, Jawa Tegah, mampu memenubi kebutuhan sosial, ekonomi, dan spiritual para anggotanya. Di antara faktor yang menentukan keberbasilan Pangestu dalam memenubi harapan para anggotanya adalah adany a komunikasi intensif antar anggota melalui pertemuan dan bawaraos (Jv, kumpul-kumpul), perbatian yang besar terbadap anggota lainnya, teladan kepemimpinan yang bagus, pembelaan terbadap nama baik paguyuban Pangestu, dan kepuasan dalam menyelami kebermaknaan prak.tik-praktik keagamaan.]

Keywords: cohesiveness, spirituality, social behavior, meaningfulness of religious practice, the defense of the good name.

\section{A. Introduction}

One of the major challenges for adherents of official religions in Indonesia is the drying of spirituality and weakening of cohesiveness in the midst of materialistic hedonistic modern world. The practices of official religions are considered too much focusing on ritual aspects, so much so that those practices lack the meaningfulness of spirituality. Therefore, some adherents of official religions begin to see spiritual/ mysticism sects/ groups have replaced the role of official religions, so that they practice both of them in order to find the true meaning of life. In other words, official religions are currently faced with crisis of trust. Some experts tried to do some researches to find the underlying causes. Rahmat Subagya, reveals the wide-spreading spiritual sects in Indonesia. The fast increasing number of spiritual sect followers are absolutely not without a real cause. He asserts that social behaviors of religious leaders have important role in making the spiritual sects gain followers rapidly. ${ }^{1}$

It could be said that the role of religion in fulfilling the hunger of spirituality declines. Hamka had spotlights the decline of the role of religions in his Menjawab Tantangan dan Kesulitan Hidup Kekinian. For him, the major religions are considered too strict. They even dragged into the issues that tend to highlight problems related to merely religious laws; allowed or forbidden (halal or haram). ${ }^{2}$ What has been taught by many Islamic leaders so far lack of spiritual aspects which on the other hand

${ }^{1}$ Rahmat Subagya, Kepercayaan, Kebatinan, Kerohaniahan dan Agama, 2nd edition (Yogyaarta: Yayasan Kanisius, 1990), p. 26.

${ }^{2}$ Moh. Soehadha, Orang Jawa Memaknai Agama (Yogyakarta: Kreasi Wacana, 2008), p. 25. 
are developed in spiritual sects. This issue has made mysticism ${ }^{3}$ more suitable to be taken on by the followers of spiritual sects. In line with Hamka, Sularso Sopater states that the emergence of Islamic Sufism or spiritual streams within Christian community can be identified as internal reactions against formalism, dogmatism, and hierarchical rigidity which are set up within those religions. These reactions are in fact reinforced by various discrepancies between doctrines of religions and realities, the teaching and the real work, dogma and morals of religious leaders. ${ }^{4}$ The efforts to find the answer ultimately are led to the choices that are not available in the existing religious systems. ${ }^{5}$

Idries Shah, an expert on Sufism states that many religious leaders deceive themselves by using the name of religion to fulfil mere intereset to power, harmony, and sex. It is based on the fact that Muslim leaders-both bureaucrats and scholars--have misused religion as a means to provide legitimacy for their intereset. However, they frequently committed violence against human dignity and religious teaching by refending their own intereset as if religion is not part of the values of humanity. ${ }^{6}$

Djohan Effendi mentions that all religions either consciously or unconsciously have entered a period of crisis which is still ongoing and fundamental. ${ }^{7}$ Conducting his research for years on three major religions: Islam, Christianity, and Jewish, Malachi Martin comes to the conclusion

${ }^{3}$ The world mysticism is derived from "mystic", which is a process that aims to fulfill human's desire, or desire to experience and to merge with God or other transcendent forces; Ensiklopedi Kepercayaan Terhadap Tuban Yang Maha Esa (Jakarta: Direktorat Kepercayaan Terhadap Tuhan Yang Maha Esa, 2006), p. 46. Mircea Eliade also discusses the mystical tradition in Islam that is later known as Sufism; Mircea Eliade, The Encyclopaedia of Religion (New York: Macmillan, 1993), p. 46. Mysticism is people's attempt to reach absolute reality of something, i.e. to communicate directly with God without intermediaries; Elizabeth M. Dowling and W. George. Scarlett, Encyclopedia of Religious and Spiritual Development (London: SAGE Publications, 2006), pp. 305-6.

${ }^{4}$ Ideally, religion must emphasize physical and spiritual aspects altogether. For example, the error of dissemination of Sufism in the society's local beliefs reflects problems on four levels of mystical path which has been discussed completely by Hamzah Fansuri, which are syareat, tarekat, hakikat, and makrifat, are interdependent; Subagya, Kepercayaan, Kebatinan, p. 76.

${ }^{5}$ Sularso Sopater, Mengenal Pokok-pokok Ajaran Pangestu (Jakarta: Pustaka Sinar Harapan, 1987), p. 7.

${ }^{6}$ Hasyim Muhammad, Dialog antara Tasawuf dan Psikologi: Telaah atas Pemikiran Psikologi Humanistik. Abraham Maslow, ed. by M. Adib Abdushomad (Yogyakarta: LKiS, 1992), pp. 4-5.

7 Djohan Effendi, "Pengantar", in Huston Smith, Agama-agama Manusia (Jakarta: Yayasan Obor Indonesia, 2001), pp. ix-x. 
that those religions are faced with crisis. None of those religions control the development of human life. Religions fail give proper answer to modern people in solving their ethical issues. In addition, religions often can not unite mankind. Furthermore, the shift values as the impact of many changes in the world have caused people to seek for true spirituality. ${ }^{8}$

Mysticism in Indonesia itself has become independent institution, which today turns out to be an alternative way in addition to official religions. Various arguments have responded to the presence of many spiritual sects in Indonesia. However, it has already become a reality. ${ }^{9}$

The total numbers of spiritual sects in Indonesia have been recorded in several institutions..$^{10}$ Widyahadikusuma states in a discussion about "Budaya Spiritual: Memposisikan Budaya Sebagai Kebudayaan, Kultural dalam Pembangunan" at Hotel Istana Pekalongan, that:

In our country, the total number of spiritual sect followers are abundant. Based on 2003 data, there were 248 spiritual sect organizations with $8,821,724$ members throughout Indonesia. The increasing number of spiritual sect adherents can also be seen from the data of Kementerian Kebudayaan dan Pariwisata. There are currently 1,515 spiritual sect

8 The tendency of shifts resulted in some impacts, such as rationalism, materialism, secularism, and nativism (spiritualism-nativistic). Nativism occurs because of the process of objectification, manipulation, and fragmentation of human life. Therefore, it makes havoc in human spirituality. In society which is experiencing high technology and information, the spiritual aspects tend to be ignored. It has led to the rapid growing of spiritualism-nativistic thought; Ahmad Watik Praktiknya, Islam dan Dakwah Pergumulan Antara Nilai dan Realitas (Yogyakarta: PP Muhammadiyah Majelis Tabligh, 1988), p. 133.

${ }^{9}$ Wongsonegoro say that spiritual sects are considered superior above religion although it is still new. It also contributes to world peace, and it is quite optimistic. The contrary view is expressed by S. Mertodipura. He states that mysticism should be regarded as a religion because mysticism presents deep meaning in the religious life. In Konggres Kebatinan Indonesia (Indonesian Mysticism Congress) II in 1956, Wongsonegoro declares that mysticism is not a new religion that would suppress religions that already exist. Yet, it will even deepen those religions. In the meantime, compromise approach was presented in Symposium Nasional Kepercayaan 1970. It was stated by Pangestu, one of the spiritual sects, that the lessons of Sang Sukma Sejati is not a religion nor is intended to change existing religions, namely Islam and Christianity. For those who have not already had religion whether Islam or Christianity, the lessons of Sang Sukma Sejati can be used as guiding light that lead and save people in this world and the hereafter; Subagya, Kepercayaan, Kebatinan, p. 76.

${ }^{10}$ One of the institutions is Direktorat Kepercayaan terhadap Tuhan Yang Maha Esa. This institution published the Ensiklopedia Kepercayaan Terhadap Tuban Yang Maha Esa that records 147 organizations, 54 communities, seven schools, three confederations, and five associations concerning spiritual sects in Indonesia. 
organizations. Moreover, approximately 245 of those organizations have established management at the national level, and the total followers in Indonesia are about ten million. ${ }^{11}$

Pangestu is an organization that has the biggest number of followers. This organization was founded in Solo in 1949. The development of Pangestu branches reacted its peak in 2010. ${ }^{12}$ In 1954, Pangestu only had 4 branches that increased to 96 in 1967. In 1982 it increased again to 158 branches and became 196 branches in 2005. Finally, it reached 203 branches in 2010.

The development of Pangestu membership is seen rapidly in Salatiga. Since 1997 Salatiga is the only municipality besides Surakarta (the birthplace of Pangestu) which has five branches. The development of Pangestu membership here also showed significant advancement. From 1963 to 1995, there were 2,857 new members. Therefore, in 1995, the total members of Pangestu in Salatiga had reached 4,102 people. ${ }^{13}$

The increasing number of members of certain organization including Pangestu shows that there is cohesiveness among its members. In addition to the of members to remain in Pangestu, it is also seen that members also attract other people to follow Pangestu.

\section{B. Group Cohesiveness and Religious Congregation}

One of the factors that determine the dynamics of group is cohesiveness. Cohesiveness is a force that gives powerful spirit to the group. A group with high cohesiveness will have sense of interest among members who accept the group's goals. Also, the members help each other in acomplishing their goals. Essentially, group cohesiveness is also called we-feeling, esprit de corps, or a sense of belonging. ${ }^{14}$

11 "Budaya Spiritual: Memposisikan Budaya sebagai Kebudayaan, Kultural dalam Pembangunan", Suara Merdeka (11 Jan 2010).

${ }^{12}$ Welcoming Speech of Pangestu's Chairman in the opening ceremony of Pangestu Congress XVI

2010 in Surakarta.

${ }^{13}$ Tiga Pulub Tiga Tabun Pangestu di Salatiga (1996), p. 10.

${ }^{14}$ In a cohesive group, members have a desire to remain in the eirek of the members. Cohesiveness is measured by level of interest of the group members. Group cohesiveness will be intact when the members have high commitment and interest in the group. A number of factors that affect the cohesiveness are: the ways that made by the group to bring together its members, the purpose of the group, the individuals' interest in the group and the leadership; Robert S. Feldman, Social Psychology: Theories, Research, and Applications (USA: Mc Graw-Hill, 1985), pp. 376-8; Hugo F. Reading, A Al-Jämi'ah, Vol. 52, No. 1, 2014 M/1435 H 


\section{S. Suciati}

In any organizations, such conditions arise if the group can gives real satisfaction to its members to stay inside the group. In the military, it is called esprit de corpses. In psychology of communication, it is called group cohesiveness which includes high team spirit, intimate interpersonal relationships, solidarity, and deep feeling. Thus, group cohesiveness can also be defined as a force that encourages all group members to remain in the group and prevent them to leave. ${ }^{15}$

A group in which consists of people who have the same attitude would tend to be more cohesive than another group of people who do not have the same attitude. Cohesiveness is also influenced by the exchange of communication within the group. ${ }^{16}$ Deutsch also adds that the feeling of members in same the group will be expressed in the form of positive responses, such as respecting others' opinions when discussing and helping each other when in trouble. The positive effects of cohesiveness will be seen with the increase of productivity through increasing motivation in order to achieve group's goals. However, in cohesive group, it does not tolerate arguments or proposals that deviate from the values of the group. ${ }^{17}$

In other words, the more cohesive the group, the more conformity members will be subject to the norms of the group. Also, it is intolerant with the deviation. ${ }^{18}$ Therefore, group cohesiveness will be closely related to satisfaction. ${ }^{19}$ Group cohesiveness is more apparent in crisis situation where lack of unity can lead to dissolution of the group. In normal Dictionary of the Social Sciences (London: Routledge and Kegan Paul, 1977), p. 39.

${ }^{15}$ Jalaluddin Rakhmat, Psikologi Komunikasi (Bandung: Remadja Rosdakarya, 1988), p. 164; Gary R. VandenBos, APA Dictionary of Psychology (Washington, DC: American Psychological Association, 2007), p. 192.

${ }^{16}$ Communication as a requirement of a cohesive group is revealed by H.J. Eysenck, Wilhelm Arnold, and Richard Meili, Encyclopedia of Psychology, vol. 1 (New York: Herder and Herder, 1972), p. 178.

${ }^{17}$ Gordon L. Dahnke and Glen W. Clatterbuck, Human Communication: Theory and Research (USA: Wadsworth Publishing Company, 1990), pp. 32-3.

${ }^{18}$ Cohesiveness is largely determined by level of interaction among the members of the group. Cohesiveness will be intact when the interaction can generate closeness among all members; Eysenck, Arnold, and Meili, Encyclopedia of Psychology, 1: 178.

${ }^{19}$ Being satisfied is to be relieved; Noah Webster and Jean L. McKechnie, Webster's Deluxe Unabridged Dictionary (Ohio: Dorset \& Baber, 1972), p. 1610. Some of effects are the pressure on the inconsistency within group, the existence of moral and satisfaction of members towards their group, the hospitality, the pattern of group thinking, democratic leadership, more cooperative members and great spirit; David L. Sills, International Encyclopedia of the Social Sciences, vol. 1 (New York: Macmillan Company, 1972), pp. 542-5. 
conditions, group cohesiveness can be seen in the satisfaction of the members with their group, mutual fondness between members, and the support for their leaders.

Little John highlights the cohesiveness associated with the compactness in group. ${ }^{20}$ According to him, the compactness can lead to effective synergy and avoid negative intrinsic energy. This is supported by the atmosphere in the group which has symptom stereotyping people outside the group. This stereotype arises because of the assumption that ingroup leaders must be respected. The solid group members will be subject to the norms of the group. The decision of respecting the leaders is among the group's satisfaction. Janis finds that group with high cohesiveness gives great pressure to its members to obey the group's standards. Cohesiveness often leads to obedience, and obedience is the main route to groupthink. ${ }^{21}$

Group cohesiveness is also formulated by Slamet Santosa as follows:

- The existence of our consciousnesses among members of the group is much stronger. It means that people often talk about 'We' rather than talking about ' $\mathrm{I}$ ';

- Friendly and loyal among the members of group;

- The members of group are willing to defend the group's reputation against any attacks from outside;

- The members of group work together in achieving a common goal which determines the progress of the group. If necessary, the members are willing to work hard and suffer for the sake of the group's cohesiveness. ${ }^{22}$

Boward identifies two kinds of group cohesiveness: group centered leader and leader centered leader. He sees that the group centered leader shows more solid. It means that this type of leaders create more friendly members. It also makes the fondness of members with group deep and strong. The opinions of members are more compatible when it is compared to leader centered leader. In addition, Festinger adds that inside a cohesive group, the social life exists. It means that the group's

${ }^{20}$ Stephen W. Littlejohn, Theories of Human Communication (USA: Woodsworth Publishing Company, 1999), pp. 288-9.

${ }^{21}$ Daniel J. Christie, The Encyclopedia of Peace Psychology (Oxford: Wiley-Blackwell, 2012), pp. 498-9.

${ }_{22}^{2}$ Slamet Santosa, Dinamika Kelompok (Jakarta: Bumi Aksara, 1992), pp. 75-7. Al-Jämi'ah, Vol. 52, No. 1, 2014 M/1435 H 


\section{S. Suciati}

members often conduct joint activities or meetings. ${ }^{23}$

The type of leadership group centered leader create group's cohesiveness. Especially, we know that cohesiveness arises in the atmosphere of ingroup or a small group. In the small group, the leader can recognize and explore all individuals. Thus, intense communication is easily established. It leads to the fondness of the leader with his members and vice versa. This intense communication occurs, if there is joint activity which is either formal or informal between leaders and members. Whyte and Lippite pay attention to the groups with autocratic, democratic, and liberal atmosphere, concluding that group's cohesiveness will appear in democratic atmosphere, and it cannot occur in the autocratic atmosphere. ${ }^{24}$ This type of leadership provides guiding and encouragement to the members to participate, so the quality of their work becomes higher. It happens because within the democratic group, there is high sense of solidarity among all members.

Relationship between leaders and their followers can also be explained by the theory of leader member exchange (LMX). ${ }^{25}$ LMX theory explains the relationship between leaders and subordinates. High LMX is characterized by the relationship between leaders and subordinates based on mutual trust, respect, and responsibility. On the contrary, low LMX is based on a contractual relationship. On the other hand, Heider explains that the formation of relationship is the results of certain factors, such as similarity, proximity, mutual respect, and past experiences.

\section{Pangestu Member Cohesiveness: Its Factors and Benefits}

The cohesiveness among Muslims Pangestu in Salatiga is caused by several factors. These factors include seven aspects which are:

- The similarity among members which includes the similarity in perception and attitude towards Pangestu and Javanese ethnicity.

- The active role of the board and the members of Pangestu which caused the optimal involvement for the advancement of the

${ }^{23}$ One of the factors that affect cohesiveness is the ways of the group to unite all its members together; Feldman, Social Psychology, pp. 376-8.

${ }^{24}$ Cohesiveness as force that describes togetherness within a group can cause effects towards the related groups. Some of the effects are the patterns of group thinking, democratic leadership, and more cooperative members; Sills, International Encyclopedia, 1: 542-5.

${ }^{25}$ Santosa, Dinamika Kelompok, p. 79. 

organization.

- Leadership approach is based on Leader Member Exchange which gives members positive attitude towards their leaders.

- Negative perception towards Pangestu about outside society stimulate the members of Pangestu to protect the reputation of the organization.

- The meaningfulness of religious practice from Pangestu gave expediency to the members for their spiritual development.

- spiritual enlightenment given by Pangestu created satisfaction with Pangestu.

Suwardi Endraswara in his book entitled Kebatinan Jawa dan Jagad Mistik Kejawen ${ }^{26}$ commens on Sasangka Jati, Pangestu's guide book, explains that Pangestu has role to deepen the understanding of religion for religious people and for people who don't embrace any religions.

It can be seen that the functions of Pangestu at least have similarity with the functions of religion for its adherents. Religions serve to overcome frustration, to preserve public order and decency, to encourage the use of intellect, and to overcome fears. ${ }^{27}$ These functions are clearly expressed by Muslims who follow Pangestu with regard to the benefits during their time in Pangestu members.

The benefits of Pangestu for the followers lay in spiritual benefits. ${ }^{28}$ It is similar to the benefits of religion for its adherents. Some benefits which are gained by the six Pangestu informants for their spiritual development include:

- Life becomes Marem, Ayem, and Tentrem (peaceful and prosperous);

- The ability to understand and accept the reality of life;

- Healthier both physically and spiritually;

- The ability to feel the love of God;

- Reforming mind;

- The ability to override 'ego';

- Strengthening the faith towards Islam;

- Getting a deep art of life;

- Manifesting wishes through Islamic Creed/Pangeran;

${ }^{26}$ Suwardi Endraswara, Kebatinan Jawa dan Jagad Mistik Kejawen (Yogyakarta: Lembu Jawa, 2011), p. 87.

${ }^{27}$ Mohammad Damami, Makna Agama dalam Masyarakat Jawa (Yogyakarta: LESFI, 2002), p. 6.

${ }^{28}$ Interwiews with Pangestu members. 


\section{S. Suciati}

- Gaining peacefulness when facing the difficulties of life's problems in life;

- Becoming more sensitive about society;

- Getting solutions for solving life problems;

- Having stronger faith in God.

The functions of Islam for Pangestu Members are implemented in the group. These functions are better experienced in Pangestu rather than in Islam. The functions that have been mentioned are spiritual functions (peacefulness, stability, tranquility, sincerity, and so on). The resignation makes them believe that only Sang Guru Sejati (God) can help them to find solution in crisis. The power of syahadat and do' $a$, are practiced in Pangestu to solve their life's problems.

The meaning of syahadat and do'a for the informants has certain variation. ${ }^{29}$ SP states that by reading and comprehending paugeran (syahadat) when facing the trouble in life along with husband and such as parents' sickess, make her stronger. Without joining the Pangestu. She might be depressed. On the other hand, for RJ, when his son started business and fell into bankrupty, he sold his house. Many people mocked her, but until now she remains strong. Different from SP and RJ, WT stated that by comprehending paugeran, his son could get a good job in Surabaya. In addition, the three other informants, SG, TP, and TR feel peace in facing their problems by dzikir "Hu Allah" and obeying paugeran.

The obidience of the informants can also be traced by the characteristics they have shown. The age of the informants varied, starting from thirties (TP and TR), sixties (SP, RJ, and SG), and eighties (W'T). There are also variant occupations of the informants, starting from retired soldiers, retired teachers, nurse, and school officers. The informants got know Pangestu by many ways; from parents, friends, and wife. Informants' roles in Pangestu varies chief of a branch, secretary of a branch, advisor and active member.

Inspite of previous characteristics, there is variation in Islamic and Pangestu behavior of the informants. Based on Islamic behavior, it can be seen that only informant SP who does not perform islamic duty sholat. Informant RJ claimed that performing sholat is just for fulfilling syareat. Meanwhile, other informants still acknowledge that shalat should not be performed just for fulfilling syareat. However, inspite of the variations in their Islamic behaviors, they still practice Pangestu rituals in the form of

${ }^{29}$ Interwiews with Pangestu informants. 
The Cohesiveness of Muslim Pangestu Members in Saalatiga manembah ${ }^{30}$ and mangest $i^{31}$ after doing salat (Ar: salāt).

Basically, the positive attitude of informants in joining Pangestu is caused by three factors namely belief, experience, and learning process. The faith of informants in Pangestu is based on the belief that Pangestu is the truth and true guidance from God. The experience includes perfoming do'a by syahadat when facing difficulties. In addition, the learning process is done by informants in the form of "nyiswa" which means always attending regularly in informal meeting and gathering.

On the other hand, the members show more committment to Pangestu itself than to Islam. In contrast, the negative perception towards Islam causes dissatisfaction for informants. The dissatisfaction of informants ${ }^{32}$ with Islam mainly comes from four things namely the diversity within Islam, the poor contents of sermons by Islamic preachers, not being able to achieve the meaningfulness of religious practice and unsympathetic Muslims' behavior.

SP stated that he doesn't understand the meaning of chanting in shalat so that he decided to stop doing shalat. RJ also added that Islamic preachers never give the details of their sermons so that the contens become too abstract and difficult to understand. According to W'T, the sermons of Islamic preachers tend to repeat the same theme; the blessing of Allah and longevity. Besides, there is no further explanation about Islamic concepts like Alif laam mïm, syahadat, life after death, and so on.

Furthermore, Sarlito Wirawan Sarwono said that the more cohesive a group, the more conformity the members are. ${ }^{33}$ High interest among members has been realized by six informants of Pangestu. They always help each other in either moral or material aspects. Suwardi Endraswara said that the relationship among spiritual sect's members is always guided by the spirit of mutual kindness. In this case, they develop a sense of mutual respect and support. They also help and feel what others feel. Their relationship is always guided by the spirit of cooperation. The fundamental nature of mystics is that they do not feel owel (fear of losing wordly things). They are united because they are in one small community. It means that they have the same ideology which is reinforced by regular

${ }^{30}$ Manembah is prayer in Pangestu way.

${ }^{31}$ Mangesti is conducting prayers and wishes after manembah.

${ }^{32}$ Interviews with Pangestu informants.

${ }^{33}$ Sarlito Wirawan Sarwono, Psikologi Sosial: Individu dan Teori-teori Psikologi Sosial (Balai Pustaka, 1997), p. 199. 


\section{S. Suciati}

meetings. ${ }^{34}$ They also persuade their family and neighbors with K3P principle (capability, sincerity, patience, sacrifice, unconditional, and without force).

Group cohesiveness also relates to the attitude of the group's leaders. The attitudes of group's leaders also show great care, compassion, and spirit of selfless. There is also a habit of ngarubke (encouraging) by leaders to members. The six informants apply the leadership principle of leader member exchange in their leadership. The meaning that is built by informants in their leadership includes:

- 5M: Momong, Momor, Momot, Mranani, Migunani (Taking care of others sincerely);

- Ngesubi (care and love), ibarat tali yang mengikat sapu lidi (like ropes that bind broom sticks);

- Pamong (someone who takes care): as a housewife, a real caretaker, knowing what the problems are, and knowing the characters of each member;

- Ablility to uplift the spirit of the members of the organization;

- Leaders are figures that reflect the teachings of Sang Guru Sejati;

- Leaders should give good examples to his members.

Furthermore, LMX (Leader Member Exchange) theory observes relationships between leaders and subordinates dynamic. High LMX is characterized by relationship between leaders and subordinates that is based on mutual trust, respect and responsibility. ${ }^{35}$

On the other hand, informants' opinion about the preachers in Islamic discussion that they followed is that the preachers tend to say about pornography in some anecdotes in their preaching sermons. Moreover, content of the lecture is worthless. Informants also compared the contents of lectures with Pangestu's teachings. In their opinion, Pangestu teaching is more enlightening and meaningful.

In understanding the concept of heaven and hell, they believe that heaven and hell is a matter of spirituality. For some informants, there are many interpretations of Koran which they understood as figurative meaning and not actual meaning as understood by most Muslims. Similarly, the strong belief of practicing manembah after shalat is also associated with this spirituality.

Unsympathetic Muslims' behavior can be solved by Dakwah bil hal,

${ }^{34}$ Endraswara, Kebatinan Jawa, pp. 68-9.

${ }^{35}$ Jerald Greenberg and Robert A. Baron, Behavior in Organizations: Understanding \&Managing the Human Side of Work (New Jersey: Pearson Education Inc., 1995), p. 480. 
that means to give good example for Muslims to follow so that it supports the effectiveness of dakwah. Perhaps, the preachers should find a new methodology that contains substantive content and competence. Less meaningfulness in religious practice can be fulfilled by a new enlightening dakwah. Islamic leaders must not create a distance or being separated from their congregation, but they should approach their congregation.

\section{Concluding Remarks}

The factors that affect the cohesiveness among the members of Pangestu are the fulfillment of social, economic, and spiritual needs within the organization. Individuals' relationships and group relationships meet these social needs. Individual relationships includes the intensity of communication between members and the application of effective leadership patterns. The level of group relationships includes the intensity of members' involvement in organization and to defend the reputation when Pangestu is under attack. The involvement of informants in Pangestu activities includes bawa raos (gathering) and sarasehan (meeting) either in the level of sub-branches or branches. The members also show great commitment to help each other in the form of material aspects either daily needs or incidental needs.

The spiritual needs are fulfilled when informants understand the meaningfulness of religious practice. The meaningfulness is created by the members' satisfaction with their organization. The perceptions of the informants towards Islam indicate certain degree of dissatisfaction. Unlike the official religions, Pangestu could encourage informants to live Marem (contented), Ayem (peaceful), and Tenterem (prosperous). Moreover, informants can also feel the presence and the love of God, keeping healthy physically and spiritually, accept the reality, combat their ego, strengthen their faith, and feel true peace in life. In addition, the informants can avoid the difficulties by practicing dhiker (Allah $\mathrm{Hu}$, narkose, and paugeran).

For the informants, Pangestu is not a new religion. In fact, it is neither deviate sect nor a heresy, but it is a place for maintaining peace and enlightening our mind. They often call Pangestu "Psychology Faculty". However, Pangestu also has the same function as religions which gives its adherents solutions for the difficulties in life, helps them to get the meaningfulness of life, and prevents them from all kinds of fear and despair. 


\section{BIBLIOGRAPHY}

"Budaya Spiritual: Memposisikan Budaya sebagai Kebudayaan, Kultural dalam Pembangunan", Suara Merdeka, 11 Jan 2010.

Christie, Daniel J., The Encyclopedia of Peace Psychology, Oxford: WileyBlackwell, 2012.

Dahnke, Gordon L. and Glen W. Clatterbuck, Human Communication: Theory and Research, USA: Wadsworth Publishing Company, 1990.

Damami, Mohammad, Makna Agama dalam Masyarakat Jawa, Yogyakarta: LESFI, 2002.

Dowling, Elizabeth M. and W. George. Scarlett, Encyclopedia of Religious and Spiritual Development, London: SAGE Publications, 2006.

Effendi, Djohan, "Pengantar", in Huston Smith, Agama-agama Manusia, Jakarta: Yayasan Obor Indonesia, 2001.

Eliade, Mircea, The Encyclopaedia of Religion, New York: Macmillan, 1993.

Endraswara, Suwardi, Kebatinan Jawa dan Jagad Mistik Kejawen, Yogyakarta: Lembu Jawa, 2011.

Ensiklopedi Kepercayaan Terbadap Tuhan Yang Maha Esa, Jakarta: Direktorat Kepercayaan Terhadap Tuhan Yang Maha Esa, 2006.

Eysenck, H.J., Wilhelm Arnold, and Richard Meili, Encyclopedia of Psychology, New York: Herder and Herder, 1972.

Feldman, Robert S., Social Psychology: Theories, Research, and Applications, USA: Mc Graw-Hill, 1985.

Greenberg, Jerald and Robert A. Baron, Behavior in Organizations: Understanding \& Managing the Human Side of Work, New Jersey: Pearson Education Inc., 1995.

Littlejohn, Stephen W., Theories of Human Communication, USA: Woodsworth Publishing Company, 1999.

Muhammad, Hasyim, Dialog antara Tasawuf dan Psikologi: Telaah atas Pemikiran Psikologi Humanistik. Abraham Maslow, ed. by M. Adib Abdushomad, Yogyakarta: LKiS, 1992.

Praktiknya, Ahmad Watik, Islam dan Dakwah Pergumulan Antara Nilai dan Realitas, Yogyakarta: PP Muhammadiyah Majelis Tabligh, 1988.

Rakhmat, Jalaluddin, Psikologi Komunikasi, Bandung: Remadja Rosdakarya, 1988. 
The Cohesiveness of Muslim Pangestu Members in Saalatiga

Reading, Hugo F., A Dictionary of the Social Sciences, London: Routledge and Kegan Paul, 1977.

Santosa, Slamet, Dinamika Kelompok, Jakarta: Bumi Aksara, 1992.

Sarwono, Sarlito Wirawan, Psikologi Sosial: Individu dan Teori-teori Psikologi Sosial, Balai Pustaka, 1997.

Sills, David L., International Encyclopedia of the Social Sciences, New York: Macmillan Company, 1972.

Soehadha, Moh., Orang Jawa Memaknai Agama, Yogyakarta: Kreasi Wacana, 2008.

Subagya, Rahmat, Kepercayaan, Kebatinan, Kerohaniahan dan Agama, 2nd edition, Yogyaarta: Yayasan Kanisius, 1990.

Tiga Pulub Tiga Tahun Pangestu di Salatiga, 1996.

VandenBos, Gary R., APA Dictionary of Psychology, Washington, DC: American Psychological Association, 2007.

Webster, Noah and Jean L. McKechnie, Webster's Deluxe Unabridged Dictionary, Ohio: Dorset \& Baber, 1972. 